\title{
LIP: a workers' community facing globalization
}

\section{Matteo Albanese}

To cite this article: Matteo Albanese (2017) LIP: a workers' community facing globalization, Labor History, 58:1, 91-105, DOI: 10.1080/0023656X.2017.1255532

To link to this article: http://dx.doi.org/10.1080/0023656X.2017.1255532

册Published online: 11 Jan 2017.

Submit your article to this journal $\pi$

щll Article views: 45

Q View related articles $\square$

View Crossmark data ¿ 


\title{
LIP: a workers' community facing globalization
}

\author{
Matteo Albanese \\ ICS University of Lisbon, Lisbon, Portugal
}

\begin{abstract}
The aim of this article is to show how at the beginning of the 1970s a community of workers in Besançon in France reacted to globalization. It deals with the culture of the working class in a French province, the level of organization of the community and how it reacted when 'its' factory was taken over by a multinational company. In seeking to understand this transformation and how the workers perceived it, it is crucial to investigate the changing role of the state. All these aspects will be developed in the sections below with the aim of better understanding the meaning of the strategy of workers' resistance in the face of a change that affected the community, the sector of production, the region and, ultimately, the working class within the Western societies.
\end{abstract}

\section{ARTICLE HISTORY}

Received 11 July 2016

Accepted 3 December 2015

\section{KEYWORDS}

Globalization; class struggle, trade unions, working class, crisis

\section{Introduction and scope}

The aim of this article is to show how at the beginning of the 1970 s a community of workers in Besançon in France reacted to globalization. It deals with the culture of the working class in a French province, the level of organization of the community and how it reacted when 'its' factory was taken over by a multinational company. In seeking to understand this transformation and how the workers perceived it, it is crucial to investigate the changing role of the state. All these aspects will be developed in the sections below with the aim of better understanding the meaning of the strategy of workers' resistance in the face of a change that affected the community, the sector of production, the region and ultimately, the working class within the Western societies.

Starting from a small case study, the goal is to reflect on wider changes in the production structures and to analyse these from below. This approach can shed light not only on the reaction of the specific community in Besançon but can help us better understand the political decline of the working class itself.

This article is mainly based on documentation collected in different French archives. The CFDT archive was crucial in order to understand the trade union dynamics together with CGT and PCF archive. I should add that the French National archive provide me with many important information which were extremely helpful in order to reconstruct the general political and social scenario. 


\section{Habitus, violence and globalization process}

Talking about LIP we are describing one of the first struggles of a worker community against the process we call globalization. In order to find competitive advantage, in terms of production and market spaces, bigger firm tend to acquire small ones. This is exactly what it did happen to LIP at the beginning of the 1970s. As a result, the French factory was supposed to be completely reorganized with the consequent loss of many jobs. The reaction of the workers community started a long fight and eventually they lost; what is crucial in this article is not only the description of this long fight which it lasted for three years but also to frame this moment as one of the first working-class reactions to a structural change of capitalism. My intention in this respect is to frame this long battle under three major elements/aspects:

(1) Is it possible to describe this fight as a strong refusal of changing not only job, without mentioning the loss of the job itself, but also habitus? How can we frame the category introduced by Pierre Bourdieu to better understand the consequences of big structural changes?

(2) Assuming that the usage of habitus, and its loss, is an acceptable category, can we analyse the violent practices that the workers decided to act enlarging the category of symbolic violence? In few words if the habitus as the acceptance of a social role has been rooted in people minds through the symbolic violence of education, is it possible that the loss of this habitus somehow 'produced' an eruption of even physical violence?

(3) How did it change during this process the role of the State in the perception of these workers ${ }^{1}$ who were engaging a big enterprise in the name of a firm as LIP that was labelled as a national champion?

\subsection{Job, community and habitus}

Bourdieu frames habitus as the complex of social relations that inscribed each one of us within social boundaries, the French philosopher assumes habitus as a very tick category within which we can find most of the everyday practices that defined the belonging to a social class. Despite the accusation of having created an iron cage from where any escape was impossible, Bourdieu stresses the importance of human-individual relationships as a way to find a way out of the habitus. In this respect, Bourdieu's idea was focused on the free and voluntary association and on the social and cultural capital exchange as the only power able to break the cage; what he did not fully investigate is what it might happen in case of a radical and fast changing of the habitus. How would people who fit perfectly within social role react if the rules suddenly change? According to Bourdieu, school and education system is the tool used by the ruling classes in order to penetrate people's minds and to force them, in some way, into the habitus cage. This process is called 'symbolic violence'. He describes a form of smooth indoctrination that makes people accept and embrace the status quo. Yet what Bourdieu did not pay too much attention to was a sudden change of scenario due to structural transformations. I am convinced this is what we can see in a case as the LIP is one big community of workers who did base all their industrial relations on their own skills and education. LIP was an old factory rooted in the traditions of the area. The presence of the factory created a kind of habitus. The everyday life of former peasants turned into workers 
by the LIP had become an element of the life of the city. The possibility of living out of the job in the LIP was one of the main aspects, one of the practices that shape the choices of the community. What the community could not forecast was a fast change of the whole scenario. When LIP was supposed to become part of a bigger Suisse firm, this habitus was about to be broken. The LIP was going to be turned into a small part of an enormous mechanism. The role of the factory within this complicated international machine was to be under the full control of the company and no longer of the community. Therefore, in this way, the community was stripped not only of the production but also of the right to decide and ultimately of its expertise. The fight, in such instances, takes on new meanings. It is not only about the defence of jobs, but about the defence of work as the cornerstone around which a whole community, and at this point a whole society, had been built until that moment. Work was the core element of the political and public discourse of the left wing, as well as that of some actors within the right wing. Affected by the transformations of the international division of labour, work as a concept was going to lose the political centrality that it once had had. ${ }^{2}$

\subsection{From symbolic violence to resistance}

As we have just seen habitus is a structuring process of the actors' social role's acceptance planted by the culture within the common sense of a social group, then perhaps this cultural hegemony is a form of violence? Is it possible that the distortion of the equilibrium created around the division of social roles can erupt in forms of physical violence? If we try to extend the concept of symbolic violence from a cultural to a structural level and we try to apply this concept to the crisis of Western societies, and to their way of production and reproduction of meanings and roles, we can easily argue that a crisis in the established cultural and social roles and in the expectations for the future could generate within a community a wave of social and personal frustration.

We may say, in the end, that this shift in timing between the change on the economical level and the change of habitus might have affected the community we are dealing with and it might have provoked the transformation of the symbolic violence that was suffered into actual physical violence.

The usage of Bourdieu's category of habitus, linked with the concept of symbolic violence, can be useful to describe these events only if we start from a broader perspective. In this sense, three points are to be stressed: the material and cultural meaning of habitus, the hard shift from one habitus to another and the relationship with the theory of the passive revolution developed by Antonio Gramsci. ${ }^{3}$

The habitus is composed by practices that have a material and a cultural meaning. Such practices are present and invasive. In describing habitus and symbolic violence in the course of his career, Bourdieu reminded us that class division or the domination of males over women is an example of habitus. We could go on with a long list of such examples. All these elements compose a set of everyday life behaviours and beliefs. As Bourdieu himself wrote in one of his most famous books, all those elements are related with the production structure in its Marxian meaning. All these aspects made a specific habitus and education is the core aspect in order to promote and to make habitus accepted. Education does not refer only to school but to all the set of behaviours and rules that make anyone of us part of a larger community; the pressure exerted by the community to everyone in order to constrain him 
within its cultural borders are a form of violence. I would like to suggest a look at the workers community of LIP in order to understand how they react to the dismantling of their factory and partially of their life and habitus. Yet when we say LIP was a firm that shaped a whole territory around it, we talk about a complex web of relations and choices. Every aspects of these workers life were somehow connected with LIP; the existence of the factory itself drove many of their personal choices. Can we assume that being an industrial skilled worker was a habitus and that in order to stick to this habitus these workers suffered a symbolic violence too? I think so. In this case is it that unlikely to reflect on violent form of protest once they were about to lose their habitus of industrial workers? As we will see in the following pages trade unions, the parish, the internal bulletin and the local newspaper, the education of children, every single aspect of workers' lives spun around the factory.

I think that the concept of habitus, used in this specific sense, is important to describe the way in which this actor, the working class at LIP, was affected by the change, while the power of the State was slowly decreasing in favour of other actors such as companies. In this respect, we could say that the State, from being the strongest actor able to rule a passive revolution, was evolving into one of the conflicting actors. The loss of the State as a ruling actor is something that accompanied the whole LIP history.

\subsection{The role of the State during globalization times}

The debate about capitalism in Europe is too wide to be summed here and it is not the aim of this article; nevertheless the studies conducted by different scholars, both historian and economist, underline the change that European and French capitalism suffered during the 1980s. In this respect, Vivien Schmidt talked about French capitalism as a State capitalism until present day, even if she said very clearly that the attitude of French State turned towards a more market-oriented capitalism at the beginning of the $1980 \mathrm{~s}^{4}{ }^{4}$ What we would like to stress here is that the internationalization process started at least a decade ${ }^{5}$ before and that LIP case is one of the most interesting ones to study also in order to contextualize this enormous shift. As Richard Kuisel showed in his studies, French State acted as a manager to drive the national economy into'modernity' during the second half of the twentieth century. Kuisel used the term 'economic management' ${ }^{\prime}$ to address what he called a conscious direction from above, the French state while it was a capitalist one remained a very active actor on the economical scene. This kind of approach was quite common in the European Western countries even if as Luc Boltansky and Eve Chiappello showed, a certain degree of paternalism was embedded in French industrial and political culture. ${ }^{7}$ French industrial culture, as well as that of Italy and Germany, though on a different scale, was characterized by a strong intervention of the State in the economy. It was a kind of hybrid regime that conceived plans to rule the public companies. The plans, at the same time, were also applied to the private sector under specific circumstances. ${ }^{8}$

In this respect, the workers of the LIP felt not only abandoned by the State in facing this international monster that was threatening their life/lives; they also accused the State of being a part of the plot to dismantle the production in the region and to destroy the whole sector. The restructuring was not a French issue but it was a process that affected the continent. The internationalization of markets and the capacity of the enterprise to survive this process determined who should live and who should die. And the State in this new scenario was starting, partially, to play a different role. 


\section{The context}

\subsection{Local specificities}

The LIP was an old factory located in the French provinces which was founded at the end of the eighteenth century. Both the town of Besancon and the surrounding region of FrancheComté developed in tandem with the factory. The largely rural region was one that for two centuries had specialized in engineering, especially the production of watches and later replaceable parts for guns and electronic systems. Within the region LIP played a primary role; the best watches, the most advanced in terms of technology, came out from the plant located in Palente, a few miles from the town, which had gradually developed into a city as industrialization progressed.

In this respect, the story of this factory, situated in a rural area that gradually industrialized, is no different from many others. The LIP turned peasants into specialized workers, proud of their skills and with a strong sense that the prosperity of the workers and of the community depended on the prosperity of the firm. It was a firm in which generation followed generation, and there was a strong expectation on the part of the young people that they would inherit the jobs of their parents. Some started out as workers but rose to become heads of their departments.

\subsection{International pressures and crisis}

During the expansion of the 1950s and especially the 1960s, the LIP management came to accept that it needed to widen its international market and distribute its productive activities. As a consequence, it signed partnership agreements with Omega and Kelton Times. Later, in 1967, Eubache SA, one of the biggest enterprises in the sector located in Switzerland bought $33 \%$ of the shares in the company.

The process of internationalization of the production and distribution did not itself cause LIP workers anxiety, since they felt a sense of security that was derived from their scarce and highly developed skills. Thus, when they symbolically occupied the factory in May 1968, it was a way of showing solidarity with other workers rather than out of any concern with changing employment patterns in LIP itself.

The CFDT, the Catholic trade union, was hegemonic among the workers of the LIP, although after 1964, CFDT was no longer a confessional trade union and so the link with Catholicism remained a purely cultural one. ${ }^{9}$

When a crisis erupted in 1973 at the LIP it took place against a background in which there was a strong sense of worker identification with the factory and, a strong sense of community cohesion, and Catholicism provided a social and cultural framework for everyday life.

No other industries in Franche-Comté employed as many skilled workers as the LIP plant, but over the years the workforce had become largely female. Women were considered as well suited to the kind of detailed, precise work that went into watch-making. In the plant at Palente, $52 \%$ of the workers were women and out of 1300 workers, only 300 were unskilled. ${ }^{10}$ There had been no substantial labour turnover at the time the crisis broke: the majority of the workers had been employed there for many years. They perceived the factory as stable place for them and as a guarantee of a safe future for their children. The future was about to change. A crucial feature of the Fordist way of production based on the idea that a single plant is able to produce a specific good from the beginning until the end was rapidly ageing. ${ }^{11}$ 
Though an old and respected company in France, and despite attempts to internationalize its activities, LIP proved unable to adapt with sufficient rapidity to changing markets. Sales between 1969 and 1972 fell steadily from 485,000 units in 1969 to 391,000 in 1971 before rising to 440,000 in $1972 .{ }^{12}$ The company's debt rose to about 25 million francs and its share of the national market fell from $20 \%$ in 1963 to $5 \%$ in 1972. It thus made sense for the Lipman family to try to sell the company. What is less clear is why a Swiss multinational should have been willing to acquire LIP given its poor state of health. At this time, Ebauches, a leading international watch producer in Switzerland, was losing significant market share in favour of Japanese manufacturers. ${ }^{13}$ It was thus interested in benefiting from the skills of the LIP workers as part of a programme of re-expanding its market shares. At the same time, it recognized that it could do this only via a drastic programme of restructuring and it was its rationalization plan that sparked the protest of the LIP workers. The plan, which unfolded on 17 April 1973, entailed not only a loss of many jobs but substantial deskilling of the workforce by making the LIP plant but one link in a chain in which different stages of production were separated in different factories.

The end of the self-sufficient model and the integration of the plant as a small part of a larger anonymous mechanism threatened to unravel the fabric not only of the factory but of the community.

Under the proposed plans of Ebauche S. A., hundreds of workers would lose their jobs and entire sectors of production would be shut down, at about half the size, the company would no longer produce watches from beginning to end. The production was to be fragmented across different factories around the world. Moreover, LIP was not the only company of its sector in crisis: the entire region, specializing in precision mechanics, was experiencing a decline in the number of employees. ${ }^{14}$ This aspect together, of course, with the loss of work places, was the shock that triggered the protest.

At this point, facing global change, LIP's workers and their organizations started to reflect about the role of a crucial actor on the stage: the State.

\subsection{The perception of the State's role}

(...) The complicity of public power is blatant: The Institute of Industrial Development (IDI), officially charged with giving help to small and medium enterprises, has to date made it a condition to act swiftly and decisively. The market for machine tools for National Education has been withdrawn from LIP for the benefit of other companies. The regional prefect, the devoted servant of the Capital, has always maintained that the LIP was in need of 'a bold restructuring' and occasionally he sends his shock troops to flatter the workers. In response to the united front Employers-Government, the workers demand the following: (...) (translation by the author) ${ }^{15}$

It is interesting to note that what was present even in the cultural and political context of a relatively conservative trade unionism, such as the one of CFDT, was the idea of an almost organic connection between the state and employers in the management, even coercive, of the situation of economic and social crisis. The CFDT in rallying workers to mobilize uses an analytical model that in those years was found mainly in France among intellectuals, students and workers movement and among political groups that ranged from the peaceful to the armed ones. The idea that the State was not simply colonized and controlled by the ruling class but that it had become itself an enemy was a crucial aspect of the so called new Marxism that was so popular in Europe during the 1960s and the 1970s. ${ }^{16}$ 
The unrest began on 13 June 1973, when the LIP directorate announced the dismissal of 480 workers out of 1000 . The previous day, during a kidnapping spree, some workers had discovered the plans for downsizing. At $11.45 \mathrm{pm}$, the police arrived and the managers were released, but then the fight began. ${ }^{17}$ The following morning, the workers assembled at the LIP and decided to resume production under self-management as a form of protest. ${ }^{18}$

The dreams, hopes and pride of an entire community - the personal histories of hundreds of people - became caught up in this attempt to resist a transnational process of capitalist reorganization.

The theoretical category of crisis is central to understand LIP's history, since the LIP struggle was only one example of a general change. According to the CFDTs:

Why is there the crisis at LIP? - Mismanagement ... probably ... Difficulty in adapting to current forms of competition for sure (...) But it is not only this. The LIP is the victim of the law of concentration which ultimately finds its purpose in the search for maximum profit. LIP is the last bastion of the French watch- and clock-making - the ones that must fight facing the giant Swiss ASSUAG, the banking group that covers the most important watchmakers trust Draft SA.

What lies behind the last LIP crisis is, in fact, a Europe-wide restructuring, since European capitalists must organize in such a way as to maintain and increase their profits to compete internationally (Japan, United States). This means jobs cuts and plant closures. This involves, apart from the LIP, in France and Switzerland 10,000 jobs at stake at numerous small and medium firms.

It is a logical consequence of the choices made for the Power (employers and government) and which appear in particular in the VI Plan (...). Massive aid given to certain industries and trusts which fit an 'international size' (Wendel, Sidelor, CSF, etc.). Outright abandonment of branches too small or too dispersed, foreign firms assigned to 'restructure' them at their benefit. This is how the English group 'Cayneman Soofi' just bought the Générale Alimentaire. ${ }^{19}$

There was here a clear awareness of the ongoing process of internationalization. To the delegates of the CFDT, the link between global competition and the crisis that had erupted in Franche-Comté was clear. The global reorganization and the transfer of production from Japan to the United States pressured the Swiss group, as though by a cascade effect, to reorganize its production in new ways. The plant in Besançon not only was reduced in numerical terms, but would have to fulfil different functions. ${ }^{20}$

The State decided which companies should be saved and which were to be sold and sacrificed to satisfy the hunger of the banks which laid behind the crisis.

In this respect, the State was no longer the ruler of different and sometimes clashing interests composed by different levels of possible agreements; this social democratic dream had faded away. ${ }^{21}$ The State took sides and it was that of the companies. Workers were left alone to their titanic clash to oppose a power against which a full victory was impossible.

The decision to occupy the factory and to start self-managing represents the sign of defeat and not a challenge to the international system. It was more a kind of withdrawal to the regional and municipal borders to escape the attack against the community from two sides: the company and the State. The perspective of the withdrawal is reinforced also by the appeal of the LIP workers towards the regional community. Calling on the citizens of Besançon to get involved in the protest in order to defend the factory is another symptom of the feeling of belonging to a whole community. It also gives an account of a defeat inside the factory and the need to enlarge the borders of the protest. In the eight internal bulletins of the factory, called LIP Unité, we find an article that explains the reasons why the committees of the workers were going to refuse the plan proposed by the French Ministry for industry. 
One of the reasons cited was that without a strategic plan not only jobs at LIP but in the whole of the region would be lost. ${ }^{22}$ Here a dichotomy was evident between the different hopes and expectations as to the role of the State. On one side, the State was the new enemy allied with the enterprises that were destroying the production in France but, on the other, LIP workers looked at intervention by the State to save them. This dichotomy can be explained using Pierre Bourdieu's concept of habitus. ${ }^{23}$ For many years, the tradition of State intervention had been reinforced by economic and social growth. It was a tradition that had become central to the ideology of the $\mathrm{CGT}_{1}{ }^{24}$ a new paradigm: a dominant or hegemonic culture, ${ }^{25}$ a habitus to use Bourdieu's category.

The trade unions, Catholic as well as socialist ones, were one of the material tools by which this culture became, step by step, hegemonic among workers. The idea of never-ending growth was a dream that clashed violently with the crisis in the beginning of the $1970 \mathrm{~s}^{26}$ This habitus was a complex composition of ideologies, practices of everyday life and cultural values that fed the entire society for three decades after the destructions of the Second World War. The idea of a third way, of a temperate capitalism between the wild U.S. liberalism and the Soviet regime, was born within the smoking ruins of Western European countries. Sustainable growth that was able to pay for an enormous welfare state with high levels of production-consumption cycle collapsed once faced with the internationalization processes. The failure of the gold standard in 1971 and the crisis of overproduction destroyed those hopes. These were all signs of the beginning of the end for a model. ${ }^{27}$

\section{Contextualizing the factory's occupation}

What we have done is not a theft: this plant belongs to us more than to those Swiss who want to destroy the LIP.28

In the workers' perception, the occupation of the factory was not a crime. This factory was their factory. They belonged to it and it was the most important plant in the region. The job in the factory was a symbol of their habitus; of the shift from the countryside to the city, from peasants to workers. This path represented an important social progress. Being a worker in a factory meant not being concerned about the rain or the sun. It meant being free from the slavery of the natural elements that for centuries had marked the life of the majority of the people all over the world. The globalization process, represented in this case by the Swiss group's acquisition of the factory, seemed to them as having a precise goal: destroying their way of life and their future.

Workers of the LIP had endured, until then, the symbolic violence entailed in the imposition of their social role quite happily. The LIP had never been a heavy environment. The workers' culture was based more on the idea that a good salary was linked to a job well done. When the sudden coming of the Swiss enterprise changed the conditions, the workers were not ready for this change of habitus. The previous cultural elements were still too strong and present. The myth of the never-ending growth was so deeply rooted that in reaction an explosion of disillusion and anger ensued.

The night before the occupation of LIP on 13 June 1973, workers had kidnapped one of the managers of the factory. Faced with the lack of information about the destiny of the plant, the workers reacted violently to what they perceived as a violence itself. ${ }^{29}$

They seized one of the managers until he agreed to reveal the details of the Eubache SA. reorganization plan. Only after that was the manager allowed to leave the factory around 23.45 when the police were already outside the place. ${ }^{30}$ 
The morning after, during a general assembly attended by all LIP workers, the decision to occupy the factory was taken. The resistance struggle against the dismissals started that morning.

The dreams, hopes and pride of an entire community, the personal stories of hundreds of people joined in an attempt to resist. And thus started the brave, desperate, proud and stubborn resistance to a transnational process. During the same assembly, it was decided that the production would be resumed in a self-management regime.

From the very beginning, one of the problems that the workers had to face was related to the defence of the factory. They divided themselves into five internal groups; one of which responsible for 'maintenance and defence'.

The main goal of this committee was exactly to oppose the $\mathrm{CRS}^{31}$ when they came to throw them out of the buildings. In the meantime, they not only occupied the buildings, but they restarted production to sell watches on their own. The news became public very soon and the enthusiasm was enormous and spread across the French left wing. Parties, trade unions, groups and everybody went to Palente to visit the experiment of a capitalistic factory turned into a'socialist' one. The mythology of self-management was still very strong in all its different declinations the French left wing had created along the years.

Socialists, Communists, Trotskyites, Leninists of different orientations, even Stalinists, and, above all, Maoist militants went to Besançon in order to understand, to see with their own eyes, to exhort and to help. For some of these groups, the LIP's fight was the clear sign that capitalism was ending and that the crisis of 1974 was the big one prophesied by Marx. The crisis was biting hard and as we see violent episodes had already occurred before the occupation. Notably, the violence was not completely out of question according to the management committee created by the workers.

It is therefore necessary to distinguish between the mass violence, that can be ascribed to a legal framework or traditions, and practices more or less accepted but tolerated, e.g. strikes, factory occupations, the demonstrations of the sequestration in public (...) ${ }^{32}$

This sentence is part of a larger flyer against the dissolution of the Gauche Proletariénne ordered by the minister of the interior Marcelin (Ministry of Internal Affairs). The CFDT at the same time tried to mark a distance between the calculated violence, usual among groups, and different types of violent acts that could occur during a social struggle as in the case of the abduction of bosses at the LIP.

The struggle, and somehow the violent tools as well, to defend a right to work was allowed and understood not only by trade unions but by the community as well. It is, indeed, interesting to mention an interview with the Archbishop of Besançon Lallier in the weekly La Croix in August 1973. The senior Catholic prelate pointed out that work is a fundamental part of life and an inalienable right of the people that Catholics must defend. He underlined the tragedy experienced by workers who lose their jobs - the very foundations of a community. ${ }^{33}$

So, again, facing the need of changing habitus, belatedly following the change in the way of production, the symbolic violence experienced might turn into physical violence, enacted by the very subjects that were suffering the drama caused by the recalled processes of time shifting.

This shifting affected all the actors and in the case of workers manifested itself in their inability to change habitus. On an individual scale, a new habitus entailed the possibility for the LIP workers to imagine a different way of living. Here the factory was the social space 
that allowed the reproduction of the social practices that lay at the foundations of the community. Now a strange enemy was ripping them out of this vital space; the space that gives sense to the process of identity building.

The only way out they saw was to withdraw themselves into the factory borders. They reclaimed their skills restarting the production and sales of their watches. They reclaimed their craftsmen's identity as if the lack of expertise was the source of the problem they were encountering. What they did not understand is that their being workers, their social identity, was questioned by the emerging international labour division. ${ }^{34}$

\subsection{Changing perspectives}

It was in this context of frustration and disillusion that the State became an enemy inasmuch as it was an ally of the enterprises. As suggested above, the State, the natural monopolist of violence, was no longer a neutral actor in the field. For the Marxists, the bourgeois State should have been conquered in order to build a communist one. But the State in the LIP context was a tool; a powerful tool in the wrong hands. What is happening here, as regards the role and nature of the State, is a significant shift in its meaning, theorization and strategy.

The State did not even try to mediate between conflicting interests. It made choices that helped the big firms to survive on a global scale and, in doing so, it doomed others to disappear. This disappearance is not simply the fading away of production as a base for the economy; it is a social, cultural and ultimately a political process. And this process became suddenly pretty clear when the minister of Interior sent orders to the CRS to clear the factory of the occupying workers.

When you see the CRS like that facing you, armed to the teeth and when you say to yourself that they said they are paid to fuck us in the face, it is stronger than you: you take all that falls into your hands and then throw it against them (...). It's stronger than you, when you see a pregnant woman running, and then her husband bludgeoned, even if you do not want to fight, you have to. It put my nerves on edge, I was in a bubble (...) We started to insult them, tell them why ... because I cannot stand them, eh, so, there's nothing to do, I can not understand why the CRS occupies our factory. ${ }^{35}$

The State - the biggest community we belong to - sent the police against them. And they did not understand that feeling of belonging was breaking confronted with the brutality of the police that simply beat them up and threw them out from their factory. Because the LIP became a badly managed factory that was on the verge of failing and for this reason it was sold to another owner. At this point, it became their own factory. And for the resisting workers the fact that the community, in the form of the French State, not only was not supporting them against the stranger, but was even fighting against them was absolutely incomprehensible.

They did not have the habitus to understand it. The State and the native soil were strong concepts even for the French left. The police taking over their factory came as a shock to them. The LIP workers at that point tried to root their fight in the territory and among the citizens. This shift from the struggle of a national working class, and in this respect, a struggle supported by the State, to a fight against the State allied with the global stranger is exactly the sign of the difficulty, theoretical but also strategic, of the workers in understanding the new world. This is the process, economical, cultural and political, that marked the defeat of the community against the globalization process. To this process, the only possible answer 
that the workers and the community had was to establish the production of watches in a former high school that the municipality gave to the workers in order to allow them to continue their struggle. At that point the dimension and the meaning of the fight changed.

A few months after the beginning of the fight the discourse changed substantially:

For seven months, we, the LIP workers, have been engaged in a hard conflict. (...) This struggle is the struggle of all workers: from the beginning of the conflict, we, the LIP workers, were surprised by the echo of our struggle and the immense solidarity that has developed around us. (...). Capitalism in France has entered a phase of profound restructuring, illustrated by significant changes in the regional economy (steel) or in professional sectors (textile, shoes, books). ${ }^{36}$

Capitalism itself had moved to a different phase. The LIP issue is the sign of a time in which all the traditional sectors of industry were reshaping. The citizens of Besançon and the Archbishop of the city are allies. This new architecture of social relationships did not include the States any more, nor the workers as unified social class. As a matter of fact, in the analysed flyers we find more references to the citizens than to the working class.

'The times are a changing', Bob Dylan sang only a few years before the events we are discussing. Thinking about a possible social and generational revolution was then feasible. Over the barricades in Paris during the weeks of May 1968, the students' movement claimed a direct democratic reform against the $V$ Republic; at the same time in many factories around the country, workers fought to participate in the decision-making as some authors like Mallet and Touraine pointed out. ${ }^{37}$

Only few years following the process of restructuring that affected Western capitalism the times really changed. The fight at that point was a defensive one. At LIP, as in other places, what began was a fight in defence of the job.

\section{Conclusions}

A long cycle, in a certain way an era, was coming to an end. Work as the main concept that shaped all the political debate until that moment was slowly disappearing. Fordism reached the height of its success and had already started its decline. New ways of production were coming and in some factories the first sign of this enormous change arrived quite soon. The internationalization process was speeding up and many branches of the classical manufacturing industry were deeply affected by this process.

In this new scenario, workers were called to suffer big changes not only in their way of life but also in the way they perceived themselves. The restructuring process was telling them loudly that their specific weight within societies was decreasing. The new shape that the capitalistic production was taking did not only involve the role that they could play inside the factories but also their social and political roles.

As a matter of fact, when production is dispersed in many different countries around the world so are the workers. Within this new frame, workers lose cohesion. The social cohesion of the working class was thought and organized around the production in terms of labour relations, the factory in terms of social relations and the party in political ones.

All these aspects characterizing the public role played by workers in Western societies was deeply rooted in the cohesion given by the factory and formed the knowledge they used to develop through years of work. The transfer of production meant death for entire regions and for whole communities. The impossibility to plan and to dream a common future made the LIP workers claim the responsibility of the managers but also of the State. This 
unfair fight marked the distance between the State and the community of workers. The State was actually bypassed by the enterprise and it could not do anything to save the community of Palente. The Swiss group was answering the challenge of globalization of the market in the unique possible way for a private enterprise. It was trying to enlarge its business and to acquire new brands in order to consolidate its position.

The State, at least according to the workers' idea, should have protected the national community from a social disaster that threatened not only Palente but the whole region and even the State itself. But the State decided not to do so and in this respect during the crisis of 1973-1974 we see the first appearing of what Bobbit calls the market-State. ${ }^{38}$ According to this reading, the Nation-State based its own legitimacy on the promise of providing welfare to its citizens based on the production and sales of goods, came to an end.

With the change of era, an era during which Western states lost their capability of being the leading force which shapes society also driving economical and social cohesion processes, the role of the State changed radically. In the global era, the State should simply provide the opportunity for everyone, within the paradigm of the free market, to develop their own individual skills.

The time for collective action seems to come to an end. The State was not dying but it was changing into something far away from the idea of a community. With the end of the concept of community, which in the case of workers was built around the factory, the factory itself, the physical place, became a bastion to defend. When even this place had been ripped away from them the last rampart was the production; the skills that proved their social and individual usefulness and shaped their own identity.

For this reason the workers at the LIP occupied the plant and after they had been thrown out of it they started the production in another building. A building that, and it is not a coincidence, was given them by the municipality of Besançon. The move from the NationState to the market-State was a long and complex path that took anextremely long time and is still in progress. The local level of government was still strongly linked to the territory, if only by proximity rather than by the way in which democracy worked, and it was thus reluctant to leave the workers to their destiny. But the destiny was marked by the change of era: from the times of collective action to the individual moment.

Those, as the workers, still waiting for the community, namely the State, to help them for the sake of the community were late vis à vis the change of paradigm. Again, inside this incapability of adjusting to these new processes, lies their desperation, their violence and their fading away as a social class able to recognize itself as a cultural and political subject.

\section{Notes}

1. Bibliothèque de Documentation International Contemporaine (BDIC) file $Q$, envelop 12,785 . This document is particularly important because is the sum, written by a member of Besancon prefecture, about the LIP situation. In order to write the analysis that was sent to Paris at the Minister of industry many interviews with workers were collected. Here we can easily find in many interviews the workers hope for a State intervention in order to save their jobs and the factory itself.

2. Castel, Les métamorphoses de la question sociale; and Chauvel, Le Destin des générations.

3. Gramsci, II Risorgimento. In the fifth volume of Quaderni del carcere (prison notebooks), Antonio Gramsci developed the concept of passive revolution as a complex process composed by cultural and structural elements by which the ruling classes could gain the cultural hegemony and later on the passivation of the subaltern social actors. 
4. Schmidt, "French capitalism"; and Smith, France in Crisis.

5. Tarrow, Democracy and Disorder; Pollard, "The rise of the service industries"; Pecqueur and Ternaux, "Éditorial Mondialisation, restructuration et gouvernance territorial"; and Marwick, The sixties cutural revolution.

6. Kuisel, Capitalism \& the State.

7. Boltansky and Chiappello, "The new spirit of capitalism", 161-188.

8. Caron and Bouvier, "L'Etat et le capitalisme”.

9. Michel, Histoire de la CFDT.

10. Attach to LIP Unitè, internal workers LIP's bulletin, 23 September 1973, BDIC, F delta res. 576/6.

11. Berger, Notre premiére modialisation; Wolff, "Les economistes face aux 'crises"'.

12. Après le romantisme de l'été, $L A$ verite sull'affaire $L I P$, disponibile presso la BDIC, Q piece, 8896 .

13. Après le romantisme de l'été, $L A$ verite sull'affaire $L I P$, op. cit.

14. Bruno and Cazes, "Le chomage des juenes en France", 75-107.

15. La complicité des pouvoir public est flagrante: L'institut de développement industriel (I.D.I.), chargé officiellement, d'apporter un aide aux petites et moyennes entreprises, a posé jusqu'à maintenant comme condition de "trancher dans le vif". Le marché des machines-outils pour l'Éducation nationale a été retiré à LIP au profit d'autres entreprises. Le Préfet de Région dévoué serviteur du Capital a toujours déclaré qu'il fallait chez LIP "une courageuse restructuration" et à l'occasion il envoie ses troupes de chocs caresser l'échine des travailleurs. En face de se front uni, Patronat-Gouvernement, ce que veulent les travailleurs c'est qui n'y ait (...). Flyers of the CFDT dated summer 1973. BDIC, F Delta res. 576/6 (my italics).

16. In this respect, the list of flyers, books, speeches might be extremely long. Just to quote few theoretical references to this view it is important to remember: L. Althusser, Lénine et la philosophie; and Negri, Crisi dello Stato-piano.

17. In a pretty romantic way this story has been told by the leftist group Gauche Proletariénne on their own journal: La Cause du Peuple, 48, 23 September 1973. Available at: BDIC, Fp 2743.

18. Piaget, LIP, 44.

19. Une mauvaise gestion ... sans doute (...). Une difficulté d'adaptation aux formes de la concurrencée actuelle ... c'est certain. Mais ce ne pas que ce la. LIP c'est la victime de la loi de la concentration qui trouve sa finalité dans la recherche du profit maximum. LIP c'est le dernier bastion de l'Horlogerie française ce lui qu'il faut abattre face au géant suisse l'A.S.S.U.A.G., groupe bancaire qui couvre le plus important des trust horlogers Ebauche SA. Ce qui se cache en fait derrière la crise LIP c'est une restructuration a l'échelle européenne car il s'agit pour les capitalistes européens, de s'organiser pour maintenir et accroitre leurs profits face à la concurrence international (Japon USA). Cela suppose de suppression d'emploi et de fermetures d'usines. Cela concerne au-delà de LIP, en France et en Suisse, 10.000 emplois en jeu à travers de nombreuses petites et moyennes enterprises. C'est une conséquence logique des choix faits pour le Pouvoir (Patronat et Gouvernement) et qui apparaissent notamment dans le VI plan. Aide massive à certains branches et certains trusts qui ont la "tailles internationale" (Wendel, Sidélor, C.S.F., etc.). Abandon pur et simple des Branches trop faibles ou trop dispersées, charges aux firmes étrangères, de les "restructurer" à leur profit. C'est ainsi que le groupe anglais "Cayneman Soof" vient de racheter la Générale Alimentaire. CFDT flyer; BDIC, F Delta res. 576/6. La crise at Lip: pourquoi? (my italics).

20. Berger, Notre première mondialisation; Cohen, La tentation hexagonale.

21. Boyer, "Wage labor"; and Capdeveille and Mouriaux, L'entre-deux de la modernité.

22. LIP Unitè del 3 settembre 1973. BDIC, F delta res. 576/6.

23. Bourdieu, La disinciton, critique sociale du jugement.

24. Dreyfus, Histoire de la CGT; M. Branciard, Histoire de la CFDT; and Courtois and Lazar, Histoire du Parti communiste français.

25. In order to contextualize the concept of cultural hegemony, see/cf. Angioni, Fare, Dire, Sentire, 169-222.

26. Marwick, The Sixties Cutural Revolution.

27. Berta, L'Italia delle fabbriche; Boyer and Freyssenet, Les modèles productifs; and Caporaso and Levine, Theories of Political Economy. 
28. C'est ne pas un vol que nous avons commis; cette usine est à nous plus qu'à ces gens Suisses qui veulent détruire l'usine. Interview published on Liberation, 21 of June 1973 and found in BDIC, Fp 2876.

29. Piaget, LIP, 44.

30. La Cause du Peuple, 48, 23 September 1973. Available at BDIC, Folders Fp 2743.

31. Compagnie Républicaine de Sécurité. Republican Security Companies a special brunch of the French police against riots and to control demonstration. They became sadly known in France during the 1970s for their brutality.

32. II y a donc lieu de distinguer entre la violence de masse qui s'inscrit dans un cadre légaliste ou à travers des traditions et une pratique plus ou moins acceptées mais tolérées, par exemple: les grèves, les occupations d'usines, les séquestration le manifestations sur la voie publique. Secteur Politique della CFDT dated Wednesday 3rd of June 1970 on GP dissolution, due to Marcellin laws, CFDT Archive Historique de la Confederation Folders 8H 1603.

33. BDIC, Fondo Duyrat, folders F delta res., 707.

34. Caron, Les résistible déclin des sociétés industrielle; Cohen, La tentation hexagonale; and Dumont, La fin des OS?

35. Quand on voit des CRS comme ca devant soi, armés jusqu'aux dents et qu'on se dit qu'ils sont payés pour nous foutre sur la gueule, c'est plus fort que soi, on prend tout ce qui nous tombe sous la main et puis on leur lance dessus (....). C'est plus fort que soi, quand on voit une femme enceinte courir, puis le mari matraqué, même si on ne veut pas se battre, il faut y aller. Ca m'a mis les nerfs en pelote, j'étais en boule (...) On a commencé à les insulter, leur dire des ... des ..., parce que moi, je peux pas le sacquer, hein, ca, y a rien à faire, je peux pas comprendre que les CRS occupent notre usine. I. Sommier contained in her PhD thesis: La Forclusion de la Violence politique: ouvriers/intellectuels en France et en Italie depuis 1968, 194. See also Charles Piaget, op. cit., 62-63.

36. LIP Unitè, 1st December 1973. BDIC, folder F delta res. 576/6.

37. Mallet, La Nuova classe operaia; Touraine, Le mouvement de mai.

38. Bobbit, The Shield of Achilles War.

\section{Disclosure statement}

No potential conflict of interest was reported by the author.

\section{Funding}

This work was supported by the Fundação para a Ciência e a Tecnologia under grant number SFRH/BPD/ 91213/2012.

\section{Notes on contributor}

Matteo Albanese is currently a post-doc fellow at ICS University of Lisbon. He completed his PhD at the European University Institute in 2011; his main field of interests deal with political and social history in modern times, comparative and global history, and history of political violence.

\section{Bibliography}

Angioni, G. Fare, dire, sentire: L'identico e il diverso nelle culture. Cagliari: II Maestrale, 2011.

Althusser, L. Lénine et la philosophie [Lenin and the philosophy]. Paris: Maspero, 1969.

Berger, S. Notre premiére modialisation. Lecons d'une échec oublié. Paris: Seuil, 2003.

Berta, G. L'Italia delle fabbriche. La parabola dell'industrialismo nel novecento. Bologna: Il Mulino, 2009. Branciard, M. Histoire de la CFDT, soixante-dix ans d'action syndicale. Paris: La Decouverte, 1990. 
Bobbit, P. The Shield of Achilles War, Peace, and the Course of History. New York: Knopf, 2002.

Boltansky, L., and E. Chiappello. "The New Spirit of Capitalism." International Journal of Politics, Culture, and Society 18, no. 3 (2005): 161-188.

Bourdieu, P. La. disinciton, critique sociale du jugement. Paris: Les Editions de Minuit, 1979.

Boyer, R. “Wage Labor, Capital Accumulation and the Crisis, 1968-82." In The French workers' Movement: Economic Crisis and Political Change, edited by Mark Kesselman with the assistance of Guy Groux. London: Allen \& Unwin, 1984: 250-269.

Boyer R., and M. Freyssenet Les modèles productifs [The Productive Models], Paris: La Dècouverte, 2000. Bruno, C., and S. Cazes. "Le chomage des juenes en France: un ètat des lieux." Revue de l'OFCE 62 (1997): 75-107.

Caporaso, J. A., and Levine, D. P. Theories of Political Economy. Cambridge: Cambridge University Press, 1992.

Caron, F. Les résistible déclin des sociétés industrielle. Paris: Perrin, 1985.

Caron, F., and J. Bouvier. "L'Etat et le capitalisme. Nouvelle structures, nouvelle problems". In L'ère industrielle et la société d'aujourd'hui. Vol 3 of Histoire économique et sociale de la France, edited by Jean Bouvier, André Armengaud, Pierre Barral, François Caron, Adeline Daumard, René Girault, Claude Willard. Paris: Presse Universitaire de France, 1982.

Capdeveille, J., and R. Mouriaux. L'entre-deux de la modernité. Histoire de trente ans. Paris: Presse de la Fondation Nationale des Sciences Politique, 1988.

Castel, R. Les métamorphoses de la question sociale: Une "chronique" du salariat. Paris: Fayard, 1995.

Chauvel, L. Le Destin des générations: Structure sociale et cohortes en France au XXe siècle. Paris: Presses Universitaires de France, 1998.

Cohen, E. La tentation hexagonale, la souveraineté à l'épreuve de la mondialisation. Paris: Fayard, 1996.

Courtois, S., and M. Lazar. Histoire du Parti communiste français [History of French Communist Party]. Paris: Presses Universitaires de France, 1995.

Dreyfus, M. Histoire de la CGT [History of CGT]. Paris: Complexe, 1995.

Dumont, J.-P. La fin des OS?. Paris: Mercure de France, 1973.

Gramsci, A. Il Risorgimento [The Risorgimento]. Vol. V of Quaderni del Carcere [Prison Notebooks]. Turin: Einaudi, 1993.

Kuisel, R. F. Capitalism \& the State in Modern France. Renovation and Economic Management in the Twentieth Century. Cambridge: Cambridge University Press, 1983.

Mallet, S. La. Nuova classe operaia. Turin: Einaudi, 1969.

Marwick, A. The Sixties Cutural Revolution in Britain, France, Italy, and the United States, 1958-1974. Oxford: Oxford University Press, 1998.

Negri, A. Crisi dello Stato-piano. Comunismo e organizzazione rivoluzionaria. Florence: CLUSF, 1972.

Pecqueur, B., and P. Ternaux. "Éditorial Mondialisation, restructuration et gouvernance territorial." Géographie Économie Société 7, no. 4 (2005): 315-319.

Piaget, C. LIP. Paris: Stock, 1973.

Pollard, S. "The Rise of the Service Industries and White Collar Employment." In Post-industrial societies, edited by Bo Gustafsson. London: Croom Helm, 1979: 5-22.

Schmidt, V. "French Capitalismtransformed, Yet Still a Third Variety of Capitalism." Economy and Society 32, no. 4 (2003): 526-554.

Smith, T. B. France in Crisis: Welfare, Inequality, and Globalization Since 1980. Cambridge: Cambridge University Press, 2010.

Sommier, I. "La Forclusion de la Violence politique: ouvriers/intellectuels en France et en Italie depuis 1968." PhD diss., University of Paris 1, 1993.

Tarrow, S. Democracy and Disorder. Oxford: Oxford University Press, 1989.

Touraine, A. Le mouvement de mai ou le communisme utopique. Paris: Seuil, 1968.

Wolff, J."Les economistes face aux 'crises' de 1929 et 1974." Vingtième Siècle: Revue d'histoire, 52, (1996): 114-124. 